\title{
EFEKTIVITAS PEMBERIAN RESTITUSI TERHADAP KORBAN TINDAK PIDANA BERDASARKAN UNDANG-UNDANG NOMOR 31 TAHUN 2014 TENTANG PERLINDUNGAN SAKSI DAN KORBAN \\ Oleh: Dien Kalpika Kasih ${ }^{1}$
}

\begin{abstract}
Victims as the injured party as a result of a criminal act shall receive compensation, one form of restitution. Awarded restitution to victims to reduce the suffering of the victims as a result of criminal offenses committed by offenders, especially to the victims of criminal acts. This restitution was arranged in Law No. 31 of 2014 on The Protection of Witnesses and Victims. Related effectiveness restitution for victims of crime also a form of state responsibility in an effort to protect its citizens.

This research aims to analyze the effectiveness of giving restitution for victim of crime and analyze those obstacles facing witness and victim protection agencies (LPSK) in the implementation of the provision of restitution based on Law Number 31 of 2014 about witness and victim protection.

Based on the result of study, it is known that giving restitution for victims of this crime it is said to be effective, until the process of granting restitution for the offender to the victim, but about how gifted as well monitoring conducted by LPSK to the victim after receiving restitution, it is said to be less effective, because there is no data associated with it. Then, associated with those obstacles faced with LPSK in facilitating, the provision of assistance for victims the crime is lack of human resources and the lack of budged in the process of the facilitating the provision of restitution.

Keyword: Effectiveness; Restitution;, Victims, Criminal Acts.
\end{abstract}

\begin{abstract}
Abstrak
Korban sebagai pihak yang dirugiakan sebagai akibat tindak pidana wajib mendapatkan ganti kerugian, salah satunya berupa restitusi. Restitusi diberikan pada korban untuk mengurangi penderitaan korban akibat tindak pidana yang dilakukan oleh perlaku,. Perihal restitusi ini juga telah diatur di dalam Undang-undang Nomor 31 Tahun 2014 tentang Perlidungan Saksi dan Korban. Efektivitas terkait pemberian restitusi bagi korban tindak pidana tersebut juga merupakan bentuk pertanggungjaawaban negara sebagai upaya untuk melindungi warganya.

Penelitian ini bertujuan untuk menganalisis efektivitas pemberian restitusi bagi korban tindak pidana serta menganalisis hambatan-hambatan yang dihadapi Lembaga Perlindungan Saksi dan Korban (LPSK) dalam pelaksanaan pembeian restitusi berdasarkan Undang-undang Nomor 31 Tahun 2014 tentang Perlindungan Saksi dan Korban.

Berdasarkan hasil penelitian, diketahui bahwa pemberian restitusi bagi korban tindak pidana ini dikatakan efektif, hingga proses pemberian restitusi dari pihak pelaku kepada korban, namun mengenai bagaimana pemberiannya serta pemantauan yang dilakukan oleh LPSK kepada korban setelah menerima restitusi, dikatakan kurang efektif, karena belum ada data-data terkait dengan hal tersebut. Kemudian, terkait dengan hambatan-hambatan yang dihadapi LPSK dalam memfasilitasi pemberian bantuan bagi korban tindak pidana adalah karena kurangnya Sumber Daya Manusia serta minimnya anggaran dalam proses memfasilitasi pemberian restitusi
\end{abstract} Kata kunci: Efektivitas; Restitusi;, Korban, Tindak Pidana

1 Magister Hukum Fakultas Hukum Universitas Jenderal Soedirman 


\section{A. Latar Belakang}

Proses penegakan hukum (peradilan pidana) bertumpu pada hukum pidana dan acara pidana, negara melalui organ-organnya mempunyai hak atau kewenangan untuk menjatuhkan pidana (ius puniendi). Di sini jika terjadi tindak pidana, maka terhadap pelakunya akan ditindak melalui proses peradilan dengan memberi sanksi pidana. Korban tindak pidana dan masyrakat secara otomatis diwakili oleh negara dengan cara mengadili dan menjatuhkan pidana yang setimpal dengan perbuatan terdakwa. Berbeda dengan zaman dahulu, korban atau keluarganya dapat langsung minta ganti kerugian atau pembalasan kepada pelaku. Fakta ini seperti dikemukakan oleh Hezel B. Kerper yaitu: ${ }^{2}$

"Pada masa lampau, menurut sejarah perkembangan hukum di negara Barat (Inggris), negara (yang diwakili oleh raja) tidak menaruh perhatian sama sekali terhadap kejahatan yang dilakukan seseorang terhadap orang lain, kecuali jika kejahatan itu dilakukan terhadap negara (raja). Pada saat itu, "pembalasan" dari seseorang yang dirugikan terhadap pelaku kejahatan (asas talio) masih diperkenankan. Bahkan seluruh

2 Bambang Waluyo, 2012. Viktimologi Perlindungan Korban \& Saksi. Jakarta: Sinar Grafika, hlm. 2.

kelurga korban dapat
melaksanakan pembalasan."

$$
\text { Dengan kelengkapan }
$$

perangkat perundang-undangan

yang mengatur lingkup perlindungan hak korban dan saksi beserta komisi/lembaga yang menjalankan fungsi untuk itu, diharapkan perlindungan korban dan saksi menjadi lebih baik. Mengingat pada kenyataannya kejahatan tidak mungkin dapat dihilangkan dan hanya dapat dikurangi. Kemungkinan kejahatan akan terus berlangsung dan meningkat. $^{3}$

Untuk itulah, pemerintah dan DPR sebagai pembentuk undang-undang menggulirkan beberapa undang-undang, antara lain Undang-undang tentang Perlindungan Saksi dan Korban, yaitu Undang-undang Nomor 31 Tahun 2014 sebagai perubahan atas Undang-undang Nomor 13 Tahun 2006 tentang Perlindungan Saksi dan Korban. Penjelasan umum undangundang itu antara lain dinyatakan:

"Dalam rangka menumbuhkan masyarakat untuk mengungkap tindak pidana, perlu diciptakan iklim yang kondusif dengan cara memberikan perlindungan hukum dan keamanan kepada setiap orang yang mengetahui atau menemukan suatu hal yang dapat membantu mengungkapkan tindak pidana yang telah terjadi dan melaporkan hal tersebut kepada penegak hukum."

\footnotetext{
${ }^{3} \mathrm{Ibid}, \mathrm{hlm} .6$.
} 


Korban lebih rentan
terhadap akibat perbuatan yang
dilakukan oleh pelaku, salah
satunya terhadap korban tindak
pidana asusila. Secara singkat
dapat dikatakan kejahatan asusila
adalah pelanggaran terhadap nilai-
nilai kesusilaan. Korban tindak
pidana asusila perlu mendapatkan
perlindungan khusus, baik secara
fisik maupun mental. Salah satu
proses perlindungan korban
tersebut dengan adanya pemberian restitusi dari pihak pelaku kejahatan kepada korban. Pemberian restitusi tersebut sebenarnya telah diberikan kepada korban yang memang layak mendapatkan haknya tersebut, seperti yang telah diberitakan bahwa kasus kekerasan seksual yang menimpa perempuan dan anak belakangan ini bertambah marak. Pemberitaan yang menghiasi media cetak dan elektronik seakan berlomba mengabarkan kasus kejahatan seksual. Selain menghukum pelaku, LPSK juga mengajak semua pihak untuk memperhatikan hak-hak korban kejahatan. ${ }^{4}$

Dengan demikian, penulis tertarik untuk melakukan penelitian tesis dengan judul "Efektivitas Pemberian Restitusi Terhadap

${ }^{4}$ http://lpsk.go.id/berita/berita detail/2475.html (diakses pada tanggal 10 November 2016 pukul 18:21 WIB)
Korban Tindak Pidana

Berdasarkan Undang-Undang

Nomor 31 Tahun 2014 tentang

Perlindungan Saksi dan korban".

\section{B. Perumusan Permasalahan}

1. Bagaimana efektivitas pemberian restitusi terhadap korban tindak pidana berdasarkan Undang-Undang Nomor 31 Tahun 2014 tentang Perlindungan Saksi dan Korban?

2. Hambatan-hambatan apa yang dihadapi Lembaga Perlindungan Saksi dan korban (LPSK) dalam pelaksanaan pemberian restitusi bagi korban tindak pidana?

\section{Metode Penelitian}

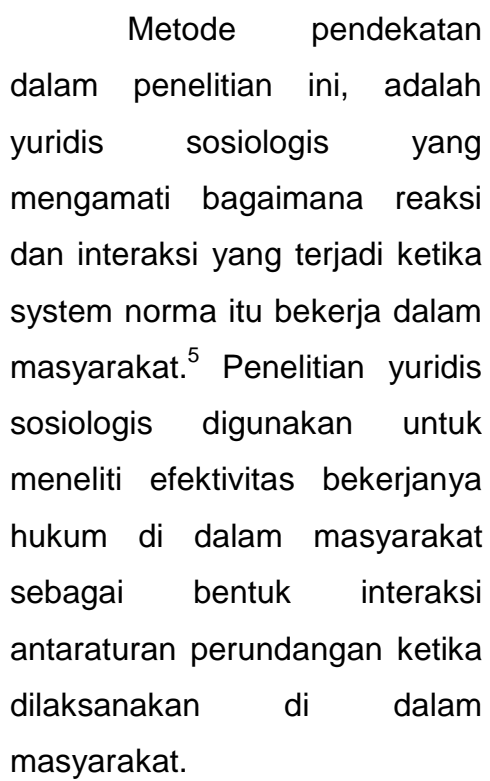

\footnotetext{
${ }^{5}$ Mukti Fajar Nur Dewata dan Yulianto Achmad, 2010. Dualisme Penelitian Hukum Normatif dan E mpi ris. Yogyakarta : Pustaka Pelajar, hlm. 47.
} 
J u rn a I I d e a $\mathrm{H} \mathrm{k} \mathrm{u} \mathrm{m}$

Vol, $4 \mathrm{No}, 1 \mathrm{M}$ a re t 2018

Ma gister H u k m F a k I tas H u k u U n i versitas

Jenderal soedirman

\section{Pembahasan}

Sebagaimana yang telah dinyatakan dalam Undang-undang Nomor 31 Tahun 2014 tentang Perlindungan Saksi dan Korban, bahwa perlindungan dimaksudkan sebagai segala upaya pemenuhan hak dan memberikan bantuan untuk memberikan rasa aman kepada saksi dan/atau korban yang wajib dilakukan oleh LPSK atau lembaga lainnya sesuai dengan ketentuan undangundang. Pemeberian perlindungan sendiri sepenuhnya bertujuan untuk memberikan rasa aman kepada saksi dan/atau korban dalam memberika keterangan pada semua tahap proses peradilan pidana. Sedangkan pemberian bantuan diberikan dalam rangka konteks pemenuhan hak atas pemulihan bagi saksi dan/atau korban. ${ }^{6}$

Kaitannya dengan tugas LPSK dalam hal pemberian fasilitas restitusi, dikatakan bahwa ada beberapa tahapan ataupun proses pengajuan permohonan restitusi kepada LPSK, yaitu:

a.

$\begin{array}{lr}\text { LPSK } & \text { menerima } \\ \text { laporan } & \text { permohonan } \\ \text { bantuan } & \text { fasilitas } \\ \text { restitusi } & \text { terhadap } \\ \text { korban tindak pidana; }\end{array}$

${ }^{6}$ Laporan Tahunan 2010 Lembaga Perlindungan Saksi dan Korban, hlm. 2. b. Setelah diterima permohonannya

kemudian dilakukan proses pemeriksaan atas laporan yang diterima LPSK terhadap korban tindak pidana;

c. Setelah itu, terkait dengan permohonan fasilitas restitusi yang dimohonkan oleh korban, akan ditindaklanjuti melalu Rapat Parirurna yang dilakukan oleh Anggota LPSK, apakah permohonan tersebut layak untuk dikabulkan ataukah permohonan tersebut belum layak untuk diberi permohonan restitusi;

d. Tahap selanjutnya adalah LPSK mengumpulkan datadata terkait dengan kerugian materiil maupun kerugian immaterial yang diderita oleh korban akibat tindak pidana yang dilakukan oleh pelaku;

e. Apabila telah dihitung besaran kerugian yang diderita oleh korban, 


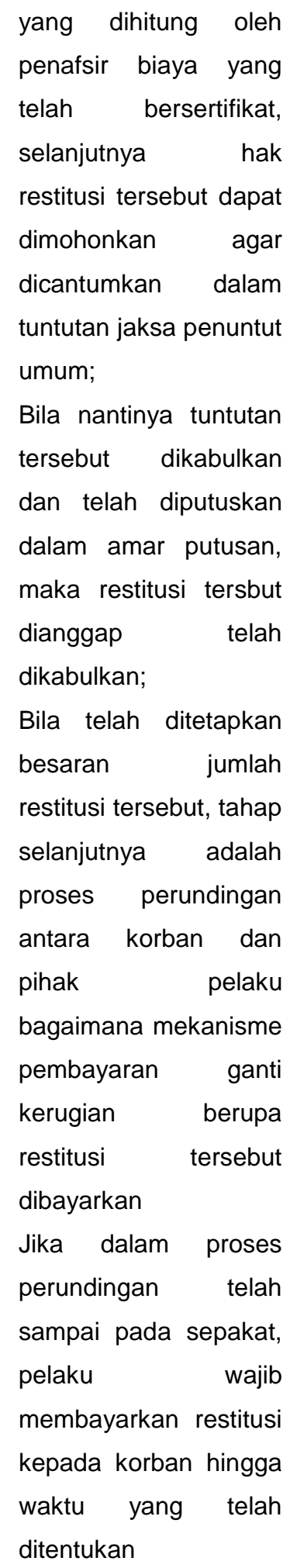

berdasarkan

kesepaktan.

i. Terkadang dalam pelaksanaannya, terdapat kendala, yakni adanya pelaku yang mampu membayar, namun tidak mau membayar restitusi. Atau ada pelaku yang tidak mampu membayar penuh besaran restitusi yang sebelumnya telah disepakati oleh korban. Hal tersebut yang nantinya akan ditindaklanjuti oleh LPSK.

j. Jika restitusi sedang berlangsung ataupun telah selesai pemberiannya, LPSK akan tetap melakukan pemantauan secara massif terkait dengan kondisi korban tindak pidana.

Terkait dengan pemberian permohonan restitusi yang dilakukan oleh LPSK, berikut telah diringkas secara jelas oleh penulis:

\begin{tabular}{|l|l|l|l|l|l|l|}
\hline $\begin{array}{l}\text { Jumlah Permohonan Restitusi } \\
\text { yang Masuk ke LPSK }\end{array}$ & \\
\hline 2010 & 2011 & 2012 & 2013 & 2014 & 2015 & \\
\hline 2 & 5 & 20 & 125 & 202 & 256 & \\
\hline
\end{tabular}


841 | J urnal Idea Hukum

Vol, $4 \mathrm{No}, 1 \mathrm{M}$ a ret 2018

Magister H u k u $\mathrm{F}$ a kultas H u k u $\mathrm{m}$ n i versitas

J endera I Soedirman

\begin{tabular}{|l|l|l|l|l|l|}
\hline \multicolumn{6}{|c|}{ Jumlah Permohonan Restitusi yang } \\
Diproses ke LPSK \\
\hline 2010 & 2011 & 2012 & 2013 & 2014 & 2015 \\
\hline 2 & 5 & 20 & 75 & 202 & 256 \\
\hline
\end{tabular}

\begin{abstract}
Berkaitan dengan tugas
LPSK sebagai penjembatan

antara pihak pelaku dengan

korban dalam hal pemberian

fasilitas restitusi ini sudah cukup efektif hingga tahap pelaksanaan restitusi yang dibayarkan pelaku kepada korban, terkait dengan pemantauan secara berkala tentang kondisi tindak pidana ini belum ada data-data yang mendukung berkaitan dengan hal tersebut.
\end{abstract}

Berdasarkan kasus-kasus di atas, dapat di lihat bahwa LPSK sebagai wadah untuk menampung hak-hak para korban tindak pidana, khususnya dalam memfasilitasi permohonan fasilitas restitusi telah melaksanakan tugas, pokok, dan fungsinya seperti yang telah diamanatkan dalam Undangundang Nomor 31 Tahun 2014 tentang Perlindungan Saksi dan Korban, khususnya yang terdapat dalam Pasal 7A; Pasal 7B; serta Pasal 8.

Sejauh ini tugas yang dilaksanakan LPSK dalam proses pemberian permohonan fasilitas restitusi telah efektif hingga tahap proses penentuan besaran biaya restitusi, namun terkait dengan tata cara, jumlah besaran ganti rugi untuk kasuskasus restitusi yang lainnya serta pemantauan apabila korban sedang atau telah memperoleh restitusi tersebut, belum ada data-data yang dapat ditindaklanjuti kembali.

Dalam hal efektifitas terkait dengan pemberian restitusi ini, terjadi kendala pada hal penegak hukumnya, yakni sumber daya manusia di LPSK yang masih kurang, sehingga menghambat mekanisme dalam hal pelaksanaan penyelidikan terkait dengan pendataan korban yang akan mengajukan permohonan restitusi tersebut.

Salah satu dasar pertimbangan diundangkannya Undang-undang Nomor 31 Tahun 2014 tentang Perldungan Saksi dan Korban adalah adanya perlindungan yang diberikan terhadap korban atas penderitaan dan kerugian, baik materiil maupun immaterial sebagai akibat tindak pidana yang dilakukan oleh pelaku. Selama ini, peraturan yang berkaitan dengan tindak pidana kesusilaan belum memberikan landasan hukum yang menyeluruh dan terpadu 
bagi tindak pidana kesusilaan.

Penanganan perkara kesusilaan berlandaskan pada pasal-pasal Undang-undang Nomor 31 Tahun 2014 memberikan perlindungan kepada saksi dan korban. Salah satu hak saksi dan korban adalah memperoleh restitusi. Hak ini diberikan kepada saksi dan/atau korban oleh pelaku sebagai bentuk ganti rugi atas penderitaan yang dialami oleh saksi dan/atau korban akibat terjadinya tindak pidana.

Berdasrkan Peraturan

Pemerintah Nomor 44 Tahun 2008 tentang Pemberian Kompenssai, Restitusi, dan Bantuan Kepada Saksi dan Korban, dalam penjelasan umum dikatakan bahwa pengaturan mengenai pemberian restitusi dilakukan dengan mengajukan permohonan oleh korban, keluarga atau kuasanya kepada pengadilan melalui LPSK. Yang dimaksud dengan pengadilan tersebut adalah pengadilan negeri yang berwenang memeriksa, mengadili, dan memutus tindak pidana yang bersangkutan. Dalam hal permohonan restitusi diajukan berdasarkan putusan pengadilan yang telah memperoleh kekuatan hukum tetap dan pelaku tindak pidana dinyatakan bersalah, LPSK mnyampaikan permohonan tersebut beserta keputusan dan pertimbangannya kepada pengadilan negeri untuk nendapatkan penetapan. Dalam hal permohonan restitusi diajukan sebelum tuntutan dibacakan, LPSK menyampaikan permohonan tersebut beserta keputusan dan pertimbangannya kepada penuntut umum. Kemudian penuntut umum dalam tuntutannya mencantumkan permohonan restutusi beserta keputusan dan pertimbangannya untuk mendapatkan putusan pengadilan. $^{7}$

Mengacu pada ketentuan Peraturan Pemerintah Nomor 44 Tahun 2008 tentang Pemberian Kompensasi, Restitusi, dan Bantuan Kepada Saksi dan Korban yang mengatur hak-hak korban salah satunya berupa restitusi ganti rugi) memiliki kelemahan secara yuridis di antaranya:

a. Undang-undang Nomor 31 Tahun 2014 yang diperkuat dengan Peraturan Pemerintah Nomor 44 Tahun 2008 yang kaitannya tentang hak restitusi bagi saksi dan korban tidak diatur secara limitative dalam tingkat banding maupun kasasi

\footnotetext{
${ }^{7}$ Penjelasan atas Peraturan Pemerintah Nomor 44 Tahun 2008 tentang Pemberian Kompensasi, Restitusi, dan Bantuan Kepada Saksi dan Korban
} 
J u r n a I I d e a $\mathrm{H} \mathrm{u} \mathrm{k} \mathrm{u} \mathrm{m}$

Vol. $4 \mathrm{No}, 1 \mathrm{M}$ a ret 2018

Ma gister H u k m F a k I tas H u k u U n i versitas

Jenderal soedirman

terhadap putusan pengadilan

dalam perkara tindak pidana

kesusilaan. Terebih lagi

terkadang penuntut umum

tidak memasukan hak restitusi

tersebut ke dalam tuntutannya

atau bila terdakwa

mengajukan banding maka

restitusi tersebut menjadi

hilang. Tentu saja hal tersebut merugikan saksi atau korban dalam memenuhi haknya

dalam memperoleh hak

restitusi. Dalam hal ini, korban

akan dirugikan karena korban

harus menerima putusan

karena apabila terdakwa

dinyatakan banding maka

secara otomatis perkara

perdatanya mengikuti

pemeriksaan banding. Apabila

tidak maka korban tidak

diperkenankan untuk

mengajukan banding atas

gugatan ganti kerugian atau

restitusi atas putusan yang

dialami korban, baik materiil

maupun immaterial.

b. Mekanisme pengajuan restitusi

dilaksankan sejak korban

melaporkan kasus yang

dialaminya kepada Kepolisian

Negara Republik Indonesia

setempat dan ditangani oleh

penyidik bersamaan dengan

penanganan tindak pidana

yang dilakukan. Penuntut \begin{tabular}{lrr} 
umum memberitahukan & \multicolumn{2}{r}{ mon } \\
kepada saksi atau & korban \\
tentang haknya & untuk \\
mengajukan & restitusi.
\end{tabular}

Selanjutnya, penuntut umum

menyampaikan jumlah

kerugian yang diderita saksi

atau korban akibat tindak

pidana bersamaan dengan

tuntutan. Mekanisme ini tidak

menghilangkan hak korban

untuk mengajukan sendiri

gugatan atas kerugiannya.

Meskipun penuntut umum

berwenang mengajukan

restitusi, tetapi mekanisme

pelaksanaannya belum diatur

dengan dengan jelas oleh

peraturan perundang-

undangan, seperti bagaimana

menentuka besar kecilnya

jumlah uang restitusi yang

diajukan, apakah

diperkenankan jika sudah

diajukan penuntut umum,

korban dapat mengajukan

restitusi sendiri. Ketentuan

pasal yang mengatur tentang

mekanismerestitusi ini tidak

terletak dalam substansi pasal.

Harusnya, hal ini dimasukan

dalam substansi pasal.

Akibatnya, polisi, jaksa, atau

pun hakim dapat langsung

memahami dan

mengintegrasikan ketentuan

pasal ini. . 
c. Dalam Peraturan Pemrintah

Nomor 44 Tahun 2008 ini tidak

menjelaskan sejauh

manaperan jaksa dan

bagaimana hubungan jaksa dengan saksi atau korban.

Selain itu, kewenangan jaksa sebagai eksekutor putusan restitusi juga tidak diatur secara tegas.

\section{E. Simpulan dan Saran}

\section{Simpulan}

1. Pemberian restitusi terhadap korban tindak pidana sejauh ini dirasa telah dikatakan kurang efektif karena belum ada data-data yang dapat ditindaklanjuti terkait dengan para korban tindak pidana yang telah mendapatkan restitusi serta kalkulasi secara rinci mengenai besaran jumlah restitusi yang dibayarkan oleh korban kepada pelaku, walaupun dikatakan bahwa dinilai dari indeks penilaian kepuasan masyarakat serta laporan dari para korban yang telah mendapat hak restitusinya yang dirasa cukup mengurangi beban penderitaannya akibat tindak pidana yang dilakukan oleh pelaku.
2. Hambatan-hambatan yang dihadapi LPSK dalam pelaksanaan pemberian restitusi bagi korban tindak pidana sejauh ini terkait dengan faktor personal, yakni kurangnya komitmen LPSK dan pihak terkait lainnya dalam implementasi pemberian bantuan dan faktor sosial, yakni kurangnya sosialisasi secara massif mengenai tugas dan fungsi LPSK serta adanya perlakuan yang berbeda dari pemerintah berdasarkan kualifikasi (jenis) korban tindak pidana terorisme. Faktor-faktor lain yang menghambat ialah dari sumber daya manusia di LPSK sendiri yang belum memadai serta terkait dengan anggaran yang masih belum mencukupi dalam hal pemberian restitusi bagi korban tindak pidana.

\section{Saran}

1. Perlu adanya pemantauan secara berkala kepada korban tindak pidana agar efektiviatas terkait dengan pemberian restitusi bagi 
845 | J u rnal Idea Hukum

Vol, $4 \mathrm{No}, 1 \mathrm{M}$ are t 2018

Magister H u k u $\mathrm{F}$ a kultas H u k u $\mathrm{m}$ n i versitas

J e nderal Soedirman

para korban tindak pidana

agar terpantau hak-haknya

terkait dengan kerugian

materiil maupun immaterial

yang dideritanya.

2. Perlu adanya peningkatan terkait dengan sumber daya manusia dalam instansi

LPSK, serta adanya peningkatan jumlah

anggaran untuk biaya

sarana dalam hal fasilitas

restitusi agar rasa aman

dan derita korban dapat

berkurang.
Restitusi, dan Bantuan

Kepada Saksi dan Korban

Internet :

Lembaga Perlindungan Saksi dan Korban, artikel, http//lpsk.go.id/berita/beritadetail/2475.html, diakses tanggal 10 November 2016 pukul 11:39 WIB.

\section{DAFTAR PUSTAKA}

Buku :

Achmad, Yulianto dan Mukti Fajar Nur Dewata, 2010. Dualisme Penelitian Hukum Normatif dan Empiris, Yogyakarta: Pustaka Pelajar.

LPSK, Laporan Tahunan 2010 Lembaga Perlindungan Saksi dan Korban.

Waluyo, Bambang, 2012. Viktimologi Perlindungan Korban dan Saksi. Jakarta: Sinar Grafika.

Peraturan Perundang-undangan :

Indonesia, Undang-undang Nomor 13

Tahun 2006 sebagai perubahan atas Undangundang Nomor 31 Tahun 2014 tentang Perlindungan Saksi dan Korban.

, Peraturan Pemerintah Nomor 44 Tahun 2008 tentang Pemberian Kompensasi, 